\title{
Assessment of oral changes resulting from the use of electronic cigarettes: Literature
}

\section{review}

\section{A valiação das alterações bucais decorrentes do uso dos cigarros eletrônicos: Revisão da literatura \\ Evaluación de cambios orales resultantes del uso de cigarrillos electrónicos: Revisión de la}

\section{literatura}

Gilvany Maria da Silva

ORCID: https://orcid.org/0000-0003-2439-2523

Centro Universitário Maurício de Nassau, Brasil

E-mail: gilmariaribeiro1@ hotmail.com

Herrison Félix Valeriano da Silva

ORCID: https://orcid.org/0000-0003-0601-6655

Faculdades Nova Esperança, Brasil

E-mail: herrison.felix.vds@gmail.com

Igor Jose de Oliveira Campos

ORCID: https://orcid.org/0000-0001-9826-4642 Universidade Federal do Rio Grande do Norte, Brasil

E-mail: igorjcampos@ufrn.edu.br

Eros Ruan de Medeiros

ORCID: https://orcid.org/0000-0003-3750-6649 Universidade Federal do Rio Grande do Norte, Brasil E-mail: erosruan70@gmail.com

Débora Frota Colares

ORCID: https://orcid.org/0000-0002-8787-5904

Universidade de Fortaleza, Brasil

E-mail: deborafrotac@live.com

Thalita Yasmin Assis de Oliveira Guedes

ORCID: https://orcid.org/0000-0002-3302-7790

Universidade Potiguar, Brasil

E-mail: thalitayasmin@ hotmail.com

Jabes Gennedyr da Cruz Lima

ORCID: https://orcid.org/0000-0001-7420-7686

Universidade Federal do Rio Grande do Norte, Brasil

E-mail: jabes.gennedyr@hotmail.com

Rafaella Bastos Leite

ORCID: https://orcid.org/0000-0002-3304-120X

Centro Universitário Maurício de Nassau, Brasil E-mail: rrafaella_bastos@hotmail.com

\begin{abstract}
The aim of the present study is to carry out a bibliographic review regarding oral changes resulting from the use of electronic cigarettes. The PubMed database was used, with the following terms and operators: "electronic cigarette" OR "e-cigarette" OR "electronic cigarettes" AND "oral health" from January 2015 to January 2020. Books were also used and epidemiological data. The inclusion criteria were articles published in Portuguese and / or English, which met the theme proposed by the study. Non-systematic literature reviews and articles that did not strictly refer to the topic were excluded. The final result was a sample of 14 articles, in which $7.14 \%(\mathrm{n}=1)$ was classified as a systematic review, $78.57 \%(\mathrm{n}=11)$ as an "in vivo" study; $7.14 \%(\mathrm{n}=1)$ as a case control study and $7.14 \%(\mathrm{n}=1)$ as a pilot study. There was a low level of published evidence on the results of oral health. The effects mentioned referred to periodontal changes and cellular damage to oral tissues. In addition, the use of electronic cigarettes has not demonstrated health security in its entirety.
\end{abstract}

Keywords: Electronic Nicotine delivery systems; Oral health; Mouth abnormalities.

\section{Resumo}

O objetivo do presente estudo é realizar uma revisão bibliográfica a respeito das alterações orais decorrentes do uso dos cigarros eletrônicos. Foi utilizada à base de dados PubMed, com os seguintes termos e operadores: "electronic cigarette" OR "e-cigarette" OR "electronic cigarettes" AND "oral health" no período de janeiro de 2015 a janeiro de 2020. Também foram utilizados livros e dados epidemiológicos. Os critérios de inclusão foram os artigos publicados 
na língua portuguesa e/ou inglesa, que atenderam ao tema proposto pelo estudo. Foram excluídas as revisões de literatura não sistemáticas e artigos que não se referiram estritamente ao tema. O resultado final foi uma amostra de 14 artigos, na qual 7,14\% (n=1) foi classificado como revisão sistemática, 78,57\% (n=11) como estudo "in vivo"; 7,14\% $(n=1)$ como estudo de caso controle e $7,14 \%(n=1)$ como estudo piloto. Foi observado um baixo nível de evidências publicadas sobre os resultados ocasionados à saúde bucal. Os efeitos citados fizeram referência a alterações periodontais e danos a nível celular dos tecidos bucais. Além disso, o uso dos cigarros eletrônicos não demonstrou segurança à saúde em sua totalidade.

Palavras-chave: Sistemas eletrônicos de liberação de nicotina; Saúde bucal; Anormalidades da boca.

\section{Resumen}

El objetivo del presente estudio es realizar una revisión bibliográfica sobre los cambios orales derivados del uso de cigarrillos electrónicos. Se utilizó la base de datos PubMed, con los siguientes términos y operadores: "cigarrillo electrónico" O "e-cigarrillo" O "cigarrillos electrónicos" Y "salud bucal” de enero de 2015 a enero de 2020. También se utilizaron libros y datos epidemiológicos. Los criterios de inclusión fueron artículos publicados en portugués y / o inglés, que cumplieran con la temática propuesta por el estudio. Se excluyeron las revisiones bibliográficas no sistemáticas y los artículos que no se refirieran estrictamente al tema. El resultado final fue una muestra de 14 artículos, en los que el 7,14\% $(\mathrm{n}=1)$ se clasificó como revisión sistemática, el 78,57\% $(\mathrm{n}=11)$ como estudio "in vivo"; 7.14\% $(\mathrm{n}=1)$ como estudio de casos y controles y $7.14 \%(\mathrm{n}=1)$ como estudio piloto. Hubo un bajo nivel de evidencia publicada sobre los resultados de la salud bucal. Los efectos mencionados se refieren a cambios periodontales y daño celular a los tejidos bucales. Además, el uso de cigarrillos electrónicos no ha demostrado la seguridad de la salud en su totalidad.

Palabras clave: Sistemas electrónicos de liberación de nicotina; Salud bucal; Malformations de la bouche.

\section{Introduction}

Tobacco consumption in the last 12 years has been reduced, results presented by the Surveillance System for Risk and Protection Factors for Chronic Diseases by Telephone Survey (Vigitel) showed that the reduction in consumption was $40 \%$ and that the national trend observed is that this harmful habit is reduced even more year after year (Dar-Odeh, 2010).

Despite the various implementations of public policies for smoking control, electronic cigarettes are becoming more popular and have been spreading under the misconception that the new form of consumption may be less harmful when compared to conventional cigarettes (Dar-Odeh, 2010). In electronic cigarettes, nicotine is released in the form of aerosol / liquid vapors, along with several other substances, including propylene glycol, vegetable glycerin, with a multitude of aromas and flavors. The idea is that nicotine and other chemicals present in the tobacco leaf undergo a process of removing impurities, theoretically resulting in a cleaner form for consumption (Farsalinos \& Stimson, 2014).

Electronic cigarettes are marketed both for recreational use and for smokers who want to minimize or stop smoking. However, the current scenario concerns health entities, considering that the use of electronic cigarettes has increased among young adults, among people who have never smoked and ex-smokers (Sutfin, 2013). The harmful effects of conventional cigarettes and the problems caused by impaired innate immunity are known and frequently appear as the object of research. For the oral cavity, inflammatory gingival and periodontal changes are known, as well as predisposing factors for oral cancer (Huilgol, 2018).

On the other hand, for electronic cigarettes, few studies have been reported on the effects of electronic cigarettes on the oral cavity. Therefore, given the lack of proven scientific data, the commercialization, import and advertising of all types of smoking devices are currently prohibited in Brazil. Studies that assessed the content of emissions, that measure health impacts and that seek to describe the risks associated with these products still have inconsistencies regarding the use and risks attributed to these devices (Sutfin, 2013).

In countries where marketing is permitted, such as the USA, electronic cigarettes are already considered a public health problem (Sutfin, 2013). Therefore, the present study aims to carry out a bibliographic review regarding oral changes resulting from the use of electronic cigarettes, as well as to discuss the role of related aspects for the correct diagnosis of these changes and treatment mechanisms involved, expanding the understanding on the subject . 


\section{Methodology}

To carry out this literature review, the PubMed database was used, using the following terms and operators: "electronic cigarette" OR "e-cigarette" OR "electronic cigarettes" AND "oral health"; and the publication date filter: articles published between January 2015 and January 2020. Books and epidemiological data were also used to construct this work.

Free articles, in Portuguese and / or English, and those in its full version, which apply to the theme proposed by the research, were included in the research in order to respond to the problems and objectives of the research. As exclusion criteria, non-systematic literature reviews and articles that did not strictly refer to the topic were excluded.

After the initial screening, the articles were downloaded and sequentially numbered and read in full, to verify the adequacy to the theme. Then, the information extracted from the selected articles were defined; categorization (case reports, clinical trial, case-control studies, pilot study, systematic reviews and meta-analyzes); interpretation and analysis of results; and the presentation of the results obtained.

At the end, after the application of the election criteria for the selection of manuscripts for the development of the study, articles that did not meet the pre-established criteria were excluded and the selected articles of greater relevance on the topic were read in their entirety for obtaining information relevant to the object of this study.

\section{Results}

A total of 33 articles were evaluated. Of these, 57, 57\% $(\mathrm{n}=19)$ were excluded: $52,63 \%(\mathrm{n}=10)$ for not referring to the proposed theme and $47,37 \%(\mathrm{n}=9)$ for being classified as a literature review. The final result was a sample of 14 articles, in which $7,14 \%(\mathrm{n}=1)$ was classified as a systematic review, $78,57 \%(\mathrm{n}=11)$ as an "in vivo" study; $7,14 \%(\mathrm{n}=1)$ as a case control study and $12.5 \%(\mathrm{n}=1)$ as a pilot study.

Table 1. Classification of articles regarding the objectives and main results found.

\begin{tabular}{|c|c|c|c|}
\hline Author (year) & Country & Purpose & Results \\
\hline $\begin{array}{c}\text { Tatullo (2016) } \\
\text { Pilot study }\end{array}$ & Italy & $\begin{array}{l}\text { To assess variations in } \\
\text { periodontal health and general } \\
\text { health in a population of smokers } \\
\text { who used electronic cigarettes for } \\
\text { a period of } 120 \text { days. }\end{array}$ & $\begin{array}{l}\text { A progressive improvement was observed } \\
\text { both in the periodontal indexes and in the } \\
\text { perception of the general health status. In } \\
\text { addition, patients reported a reduced need } \\
\text { for smoking. }\end{array}$ \\
\hline $\begin{array}{l}\text { Sundar (2016) } \\
\text { In vivo study }\end{array}$ & U.S & $\begin{array}{l}\text { To determine mechanisms of } \\
\text { gingival epithelial inflammation } \\
\text { and premature senescence caused } \\
\text { by aerosols of electronic } \\
\text { cigarettes in epithelial cells and } \\
\text { fibroblasts of the periodontal } \\
\text { ligament. }\end{array}$ & $\begin{array}{l}\text { They highlighted the pathological role of } \\
\text { FB (with or without nicotine) for cells and } \\
\text { tissues in the oral cavity. The results } \\
\text { showed that CE caused an increase in } \\
\text { oxidative / carbonyl stress and } \\
\text { inflammatory processes with cytokine } \\
\text { release in periodontal ligament fibroblasts, } \\
\text { progenitors of the human gingival } \\
\text { epithelium (HGEPp) and EpiGingival 3D } \\
\text { epithelium. They found an association } \\
\text { between the levels of prostaglandin-E2 and } \\
\text { cyclooxygenase-2, and the positive } \\
\text { regulation of the receptor for end products } \\
\text { of advanced glycation (RAGE) by carbonyl } \\
\text { stress in the epithelium / gingival tissue. } \\
\text { DNA damage was also observed along with } \\
\text { a reduction in the histone deacetylase } 2 \\
\text { (HDAC2) enzyme through RAGE- } \\
\text { dependent mechanisms in the gingival } \\
\text { epithelium. }\end{array}$ \\
\hline
\end{tabular}




\begin{tabular}{|c|c|c|c|}
\hline $\begin{array}{l}\text { Cho (2017) } \\
\text { In vivo study }\end{array}$ & $\begin{array}{l}\text { South } \\
\text { Korea }\end{array}$ & $\begin{array}{l}\text { To assess the relationship } \\
\text { between the use of electronic } \\
\text { cigarettes and oral health, } \\
\text { including 'gum pain and / or } \\
\text { bleeding', 'pain on the tongue and } \\
\text { / or inside the cheek', and 'cracked } \\
\text { or broken teeth' among } \\
\text { adolescents. }\end{array}$ & $\begin{array}{l}\text { Based on the results, the chances of cracked } \\
\text { or broken teeth among users of electronic } \\
\text { cigarettes and former users of electronic } \\
\text { cigarettes were significantly higher when } \\
\text { compared to those who never used } \\
\text { electronic cigarettes. The chances of pain in } \\
\text { the tongue and / or cheek among daily users } \\
\text { of electronic cigarettes were also } \\
\text { significantly higher. }\end{array}$ \\
\hline $\begin{array}{l}\text { Huilgol (2018) } \\
\text { In vivo study }\end{array}$ & U.S & $\begin{array}{l}\text { To analyze whether there is an } \\
\text { association between the use of } \\
\text { electronic cigarettes and factors } \\
\text { related to oral health. }\end{array}$ & $\begin{array}{l}\text { The daily use of electronic cigarettes was } \\
\text { reported by } 4,957 \quad(1.1 \%) \text { of the } \\
\text { interviewees. The results of the multivariate } \\
\text { analysis showed that the daily use of } \\
\text { electronic cigarettes was associated with a } \\
78 \% \text { higher chance of problems related to } \\
\text { oral health (HR } 0.95 \text {, CI 1.39-2.30; P } \\
<0.001 \text { ). }\end{array}$ \\
\hline $\begin{array}{l}\text { Alharthi (2018) } \\
\text { In vivo study }\end{array}$ & $\begin{array}{c}\text { Saudi } \\
\text { Arabia }\end{array}$ & $\begin{array}{l}\text { To evaluate the impact of } \\
\text { smoking on periodontal tissues, in } \\
\text { smokers who use conventional } \\
\text { cigarettes (G1) and electronic } \\
\text { cigarettes (G2), and non-smokers } \\
\text { (G3). }\end{array}$ & $\begin{array}{l}\text { The results showed that at } 3 \text { and } 6 \text { months } \\
\text { of follow-up, the plaque index }(\mathrm{P}<0.05) \\
\text { and the probing depth ( } \mathrm{P}<0.05) \text { were } \\
\text { significantly higher in } \mathrm{G} 1 \text { compared to } \mathrm{G} 2 \text {. } \\
\text { At the beginning of the study, probing } \\
\text { bleeding was significantly greater in } \mathrm{G} 3 \\
\text { compared to } \mathrm{G} 1 \text { and } \mathrm{G} 2(\mathrm{P}<0.01) \text {. At } 3 \text { and } \\
6 \text { months of follow-up, plaque index ( } \mathrm{P} \\
<0.05 \text { ) and probing depth ( } \mathrm{P}<0.05) \text { were } \\
\text { significantly higher in } \mathrm{G} 1 \text { compared to G3, } \\
\text { during the same period. } \\
\text { At } 3 \text { and } 6 \text { months, there was no significant } \\
\text { difference in the mean plaque index, } \\
\text { bleeding on probing and probing depth } \\
\text { between } \mathrm{G} 2 \text { and } \mathrm{G} 3 \text {. }\end{array}$ \\
\hline $\begin{array}{c}\text { Akinkugbe (2018) } \\
\text { In vivo study }\end{array}$ & U.S & $\begin{array}{l}\text { This study investigated associations } \\
\text { between the use of conventional and } \\
\text { electronic cigarettes, and the oral health } \\
\text { status of a representative sample of } \\
\text { adolescents. }\end{array}$ & $\begin{array}{l}\text { The use of conventional cigarettes and } \\
\text { electronic cigarettes were also associated } \\
\text { with greater chances of self-reported dental } \\
\text { problems, although to a lesser extent. }\end{array}$ \\
\hline $\begin{array}{l}\text { Alqahtani (2019) } \\
\text { In vivo study }\end{array}$ & $\begin{array}{c}\text { Saudi } \\
\text { Arabia }\end{array}$ & $\begin{array}{l}\text { The aim of the present study was } \\
\text { to compare cotinine levels in } \\
\text { perimplant succulent fluid } \\
\text { between cigarette smokers, } \\
\text { hookah users, electronic cigarette } \\
\text { users and non-smokers.. }\end{array}$ & $\begin{array}{l}\text { Perimplant plaque index and probing depth } \\
\text { were significantly higher among cigarette } \\
\text { smokers, hookah smokers and users of } \\
\text { electronic cigarettes compared to non- } \\
\text { smokers. Bleeding from peri-implant } \\
\text { sodination was most often manifested in } \\
\text { non-smokers. The volume of perimplant } \\
\text { implant intrasucular fluid was significantly } \\
\text { higher among cigarette smokers, hookahs } \\
\text { and users of electronic cigarettes, than non- } \\
\text { smokers. Cotinine levels were significantly } \\
\text { higher in the perimplant implant } \\
\text { intrasucular fluid of cigarette smokers and } \\
\text { electronic cigarette smokers than non- } \\
\text { smokers. }\end{array}$ \\
\hline $\begin{array}{l}\text { Binshabaib (2019) } \\
\text { In vivo study }\end{array}$ & $\begin{array}{c}\text { Saudi } \\
\text { Arabia }\end{array}$ & $\begin{array}{l}\text { The aim of this study was to } \\
\text { compare the periodontal clinical } \\
\text { status and cytokine profile of } \\
\text { gingival fluid (CFG) between } \\
\text { conventional cigarette smokers } \\
\text { (G1), electronic cigarette users } \\
\text { (G2) and non-smokers (G3). }\end{array}$ & $\begin{array}{l}\text { The mean scores of plaque index, probing } \\
\text { depth and level of clinical insertion were } \\
\text { significantly higher among individuals in } \\
\text { G1 than in G3. Probing bleeding was most } \\
\text { frequently manifested among patients in } \\
\text { G3. Compared to G3, marginal bone loss } \\
\text { was significantly greater in groups G1 and } \\
\text { G2. The fluid volume of the marginal } \\
\text { cracks was significantly higher in G } 1 \\
\text { compared to groups } 2 \text { and } 3 \text {. The }\end{array}$ \\
\hline
\end{tabular}




\begin{tabular}{|c|c|c|c|}
\hline & & & $\begin{array}{l}\text { concentrations of IL- } 1 \beta \text {, IL- } 6 \text {, IFN- } \gamma \text {, TNF- } \\
\alpha \text { and MMP- } 8 \text { were significantly higher in } \\
\text { the samples of marginal cleft fluids in G1 (P } \\
<0.05 \text { ) than in G2 and } 3 \text {. }\end{array}$ \\
\hline $\begin{array}{l}\text { Holliday (2019) } \\
\text { Systematic review }\end{array}$ & UK & $\begin{array}{l}\text { A systematic review was carried } \\
\text { out to evaluate the in vitro effects } \\
\text { of nicotine on human gingiva, } \\
\text { periodontal ligament and oral } \\
\text { epithelial cells, specifically: cell } \\
\text { viability, cell fixation, cell } \\
\text { proliferation and production of } \\
\text { inflammatory mediators, in } \\
\text { tobacco users. }\end{array}$ & $\begin{array}{l}\text { The nicotine levels found in tobacco } \\
\text { smokers, nicotine users on replacement } \\
\text { therapy and users of electronic cigarettes, } \\
\text { are unlikely to be cytotoxic to human } \\
\text { periodontium cells, although saliva levels in } \\
\text { smokeless tobacco users may be high or } \\
\text { enough to achieve cytotoxicity. }\end{array}$ \\
\hline $\begin{array}{l}\text { Atuegwu (2019) } \\
\text { Case-control study }\end{array}$ & U.S & $\begin{array}{l}\text { The aim of this study was to } \\
\text { evaluate the association between } \\
\text { the use of nicotine in electronic } \\
\text { devices and periodontal disease. }\end{array}$ & $\begin{array}{l}\text { The results showed that users of nicotine } \\
\text { and electronic devices increased the } \\
\text { chances of being diagnosed with gum } \\
\text { disease (OR 1.76, 1.12-2.76) and bone loss } \\
\text { around the teeth (OR 1.67, 1.06- } 2.63 \text { ). } \\
\text { These odds were higher among participants } \\
\text { with a history of marijuana and a history of } \\
\text { illicit drug use. }\end{array}$ \\
\hline Cichonska (2019) & Poland & $\begin{array}{l}\text { The aim of this study was to } \\
\text { estimate changes in the } \\
\text { physicochemical properties in the } \\
\text { saliva collected from users of } \\
\text { electronic cigarettes. }\end{array}$ & $\begin{array}{l}\text { Among electronic cigarette users, } \\
\text { statistically significant differences were } \\
\text { observed in the values of lysozyme and } \\
\text { lactoferrin; however, no statistically } \\
\text { significant differences were found for the } \\
\text { IgA value. In the group of traditional } \\
\text { cigarette smokers, statistically significant } \\
\text { differences were observed between all } \\
\text { parameters tested in relation to the group of } \\
\text { non-smokers. In relation to IgA, statistically } \\
\text { significant differences were found between } \\
\text { users of electronic cigarettes and smokers of } \\
\text { traditional cigarettes, with a disadvantage } \\
\text { for the latter. }\end{array}$ \\
\hline $\begin{array}{c}\mathrm{Ji}(2019) \\
\text { In vivo study }\end{array}$ & U.S & $\begin{array}{l}\text { The aim of this study was to } \\
\text { assess whether aerosol exposure } \\
\text { from electronic cigarettes } \\
\text { impacted the genetic pathways of } \\
\text { normal human oral keratinocytes, } \\
\text { in particular the response path to } \\
\text { unfolded protein. }\end{array}$ & $\begin{array}{l}\text { The results indicated that aerosols in } \\
\text { electronic cigarettes positively regulate the } \\
\text { genes of the response pathway to unfolded } \\
\text { proteins in normal human oral } \\
\text { keratinocytes. }\end{array}$ \\
\hline $\begin{array}{l}\text { Jeong (2019) } \\
\text { In vivo study }\end{array}$ & $\begin{array}{l}\text { South } \\
\text { Korea }\end{array}$ & $\begin{array}{l}\text { The aim of this study was to } \\
\text { examine the association between } \\
\text { tobacco use through conventional } \\
\text { cigarettes and electronic } \\
\text { cigarettes with periodontal } \\
\text { disease. }\end{array}$ & $\begin{array}{l}\text { Periodontal disease was more prevalent } \\
\text { among users of electronic cigarettes (OR } \\
2.34,1.52-3.59) \text { than users of conventional } \\
\text { cigarettes (OR }=2.17,1.76-2.68 \text { ). In } \\
\text { addition, electronic cigarette users had a } \\
\text { significant relationship with tooth decay, } \\
\text { toothache and dental damage. }\end{array}$ \\
\hline $\begin{array}{l}\text { Vora; Benjamin } \\
\text { (2019) } \\
\text { In vivo study }\end{array}$ & U.S & $\begin{array}{l}\text { This study aimed to evaluate self- } \\
\text { reported gum disease among } \\
\text { users of electronic cigarettes and } \\
\text { users of other tobacco products. }\end{array}$ & $\begin{array}{l}\text { The groups with the highest relative } \\
\text { chances for diagnosing periodontal disease } \\
\text { were pipe users (OR } 3.1,1.5-6.4) \text {, users of } \\
\text { electronic cigarettes (OR 2.6, 1.6-4.3), users } \\
\text { of several tobacco products (OR 2.8, 2.3- } \\
3.5 \text { ) and ex-smokers (<12 months) (OR 2.8, } \\
2.1-3.7 \text { ). }\end{array}$ \\
\hline
\end{tabular}




\section{Discussion}

Few studies are published on the potential health consequences of electronic cigarettes and on its effectiveness as a strategic method in helping smoking cessation. Studies carried out with samples of the chemical vapors and liquid substances used in these devices, warned about the harmfulness of toxic and carcinogenic substances, similar to those found in conventional cigarette smoke (Besaratinia, 2017). The concentrations of most carcinogenic compounds present in the aerosols of electronic cigarettes are lower than those present in conventional cigarette smoke, however there is no "safe" level of exposure given the potential of carcinogens (Vora, 2019).

The literature shows that reports of electronic systems associated with nicotine started in 1963, developed by tobacco companies. Research carried out at the University of California, San Francisco, found that in 1990 Philip Morris began to develop a device that aerolized a nicotine solution, using technology for pharmaceutical applications, as it was not known how such products would be designed by Food and Drug Administration. The widespread intention was to solve health problems and reduce the number of smokers, in a kind of nicotinic therapy by changing the form of consumption (Farsalinos \& Stimson, 2014).

Research found that some models of electronic cigarettes marketed "without nicotine", contained low levels of nicotine. The results also showed that half of the samples contained four tobacco-specific nitrosamines (NNN, NNK, NAB and NAT), the first two being classified as carcinogenic to humans (Sutfin, 2013).

The acute use of electronic cigarettes can trigger oxidative stress and increase resistance to airflow, and cause changes in the secretion of proteins from the immune system in human airways. Pulmonary repercussions are important factors in observing the consequences caused by smoking (Besaratinia, 2017).

Ganapathy (2017), examined the effects of aerosol exposure from electronic cigarettes on possible DNA damage in oral and lung epithelial cells. The results presented showed that exposure to aerosols from electronic cigarettes can cause significant levels of mutagenic DNA damage. Observation regarding the mechanisms that modulate DNA damage, identified an increase in reactive oxygen species, a decrease in total antioxidant capacity and a decrease in the expression of proteins essential for the repair of DNA damage; potentially increasing DNA damage and the risk of cancer. Yang, Sandeep \& Rodriguez (2020) in a systematic review gathered evidence from available research on the impact of electronic cigarette use on oral health. Reports of exposure to electronic cigarettes were associated with an increased risk of deteriorating periodontal, dental and gum health, as well as changes in the oral microbiota. It has also been reported that vapors generated by electronic cigarettes have cytotoxic, genotoxic and carcinogenic properties.

\section{Conclusion}

The study presented a current review of the implications that electronic cigarettes can have in the oral cavity. There was a low level of published evidence on the results of oral health. The effects cited referred to periodontal changes and damage at the cellular level of oral tissues. It is worth mentioning that the use of electronic cigarettes is not completely safe for health.

\section{References}

Alharthi, S. S. Impact of cigarette smoking and vaping on the outcome of full-mouth ultrasonic scaling among patients with gingival inflammation: a prospective study. Clinical Oral Investigations. 23(6):10.

Akinkugbe, A. A. (2018). Cigarettes, E-cigarettes, and Adolescents' Oral Health: Findings from the Population Assessment of Tobacco and Health (PATH) Study. International \& American Associations for Dental Research. 4(3):10. 
Research, Society and Development, v. 10, n. 2, e14410212146, 2021

(CC BY 4.0) | ISSN 2525-3409 | DOI: http://dx.doi.org/10.33448/rsd-v10i2.12146

Alqahtani, F. (2019). Comparison of cotinine levels in the peri-implant sulcular fluid among cigarette and waterpipe smokers, electronic-cigarette users, and nonsmokers. Clin Implant Dent Relat Res. 21(4): 1-6.

Atuegwu, N. C. (2019). Association between Regular Electronic Nicotine Product Use and Self-Reported Periodontal Disease Status: Population Assessment of Tobacco and Health Survey. International Journal of Environmental Research and Public Health. 16(1): 1263.

Besaratinia, A. (2017). An opportune and unique research to evaluate the public health impact of electronic cigarettes. Cancer Causes Control. 28(1): 11671171.

Binshabaib, M. (2019). Clinical periodontal status and gingival crevicular fluid cytokine profile among cigarette-smokers, electronic-cigarette users and neversmokers. Archives of Oral Biology. 102(1): 212-217.

Cho, J. H. (2017). The association between electronic-cigarette use and self-reported oral symptoms including cracked or broken teeth and tongue and/or inside-cheek pain among adolescents: A cross-sectional study. Plos one. 12(7):1-10.

Cichonska, D. (2019). (2019). Influence of Electronic Cigarettes on Selected Antibacterial Properties of Saliva. Int. J. Environ. Res. Public Health. 16(4433): 10 .

Dar-Odeh, N. (2010). Narghile (water pipe) smoking among university students in Jordan: prevalence, pattern and beliefs. Harm Reduction Journal. 7(10):10.

Farsalinos, K. E., \& Stimson, G. V. (2014). Is there any legal and scientific basis for classifying electronic cigarettes as medications? International Journal of Drug Policy. 25(3): 340-345.

Ganapathy, V. (2017). Electronic cigarette aerosols suppress cellular antioxidant defenses and induce significant oxidative DNA damage. Plos one. 12(5):10.

Holliday, R. S. (2019). Effect of nicotine on human gingival, periodontal ligament and oral epithelial cells. A systematic review of the literature. Journal of Dentistry. 86(1): 81-88.

Huilgol, P. (2018). Association of e-cigarette use with oral health: a populationbased cross-sectional questionnaire study. Journal of Public Health. 41(2):354361.

Ji, E. H. (2019). E-cigarette aerosols induce unfolded protein response in normal human oral keratinocytes. Journal of Cancer. 10(27):10.

Jeong, W. (2019). Associations of electronic and conventional cigarette use with periodontal disease in South Korean adults. J Periodontol. 91(1): 55-64.

Sundar, I. K. (2016). E-cigarettes and flavorings induce inflammatory and pro-senescence responses in oral epithelial cells and periodontal fibroblasts. Oncotarget. 7(47):10.

Sutfin, E. L. (2013). Electronic cigarette use by college students. Drug Alcohol Depend. 131(2): 214-221.

Tatullo, M. (2016). Crosstalk between oral and general health status in e-smokers. Medicine (Baltimore). 95(49):10.

Yang, I., Sandeep, S., \& Rodriguez, J. (2020). The oral health impact of electronic cigarette use: a systematic review. Critical Reviews in Toxicology. 50(2):10.

Vora, M. V. (2019). Tobacco-use patterns and self-reported oral health outcomes: A cross-sectional assessment of the Population Assessment of Tobacco and Health study (2013-2014). J Am Dent Assoc. 150(5): 332-344. 